\title{
9p Partial Monosomy and Disorders of Sex Development: Review and Postulation of a Pathogenetic Mechanism
}

\author{
Shane C. Quinonez, ${ }^{1}$ John M. Park, ${ }^{2}$ Raja Rabah, ${ }^{3}$ Kailey M. Owens, ${ }^{1}$ Beverly M. Yashar, ${ }^{4}$ \\ Thomas W. Glover, ${ }^{1,4}$ and Catherine E. Keegan ${ }^{1,4 *}$ \\ ${ }^{1}$ Department of Pediatrics, Division of Genetics, University of Michigan, Ann Arbor, Michigan \\ ${ }^{2}$ Department of Urology, University of Michigan, Ann Arbor, Michigan \\ ${ }^{3}$ Department of Pathology, University of Michigan, Ann Arbor, Michigan \\ ${ }^{4}$ Department of Human Genetics, University of Michigan, Ann Arbor, Michigan
}

Manuscript Received: 18 January 2013; Manuscript Accepted: 27 March 2013

Deletion of the distal segment of 9p causes a syndrome comprising trigonocephaly, minor anomalies, and intellectual disability. Patients with this condition also frequently present with genitourinary abnormalities including cryptorchidism, hypospadias, ambiguous genitalia, or $46, \mathrm{XY}$ testicular dysgenesis. The region responsible for the gonadal dysgenesis has been localized to 9p24.3 with the likely responsible gene identified as DMRT1. Similar to patients with other molecular causes of $46, \mathrm{XY}$ gonadal dysgenesis, patients with partial del $9 \mathrm{p}$ have an increased risk of gonadoblastoma. We present two patients with $46, \mathrm{XY}$ gonadal dysgenesis due to partial 9p monosomy. Both patients were also diagnosed with gonadoblastoma following gonadectomy at an early age. Chromosomal microarray analyses refined the cytogenetic abnormalities and allowed potential genotype-phenotype relationships to be determined. We also review the literature as it pertains to partial 9p monosomy, genital abnormalities and gonadoblastoma and note that a large percentage of affected patients present with two copy number variations. We propose that a two-hit mechanism may be involved in the incomplete penetrance and variable expressivity of partial $9 \mathrm{p}$ monosomy and an abnormal genital phenotype. The significant percentage of gonadoblastoma in patients with $46, \mathrm{XY}$ complete gonadal dysgenesis due to partial 9p monosomy also continues to support the necessity of gonadectomy in this patient population. $\odot 2013$ Wiley Periodicals, Inc.

Key words: distal monosomy 9p; 9p partial monosomy; disorders of sexual development; gonadoblastoma

\section{INTRODUCTION}

In humans and other mammals, sex determination is initially made in the bipotential gonad with subsequently produced gonadal hormones responsible for the differentiation of male- and female-specific characteristics. Expression of the $S R Y$ (sex-determining region of $\mathrm{Y}$ ) gene, located on the $\mathrm{Y}$ chromosome in mammals, is
How to Cite this Article:

Quinonez SC, Park JM, Rabah R, Owens KM, Yashar BM, Glover TW, Keegan CE. 2013. 9p partial monosomy and disorders of sex development: Review and postulation of a pathogenetic mechanism. Am J Med Genet Part A 161A:1882-1896.

responsible for the initial determination step that yields a male gonad [Sekido and Lovell-Badge, 2009]. SRY, largely through its upregulation of Sox9 expression, leads to the differentiation of Sertoli cells and an eventual male phenotype. In the absence of SRY and the failed upregulation of SOX9, the activation of beta-catenin signaling, through Wnt4 and Rspo1 activity, drives the bipotential precursor cells toward granulosa cell differentiation [Sekido and Lovell-Badge, 2009]. Abnormalities in the components of sex development, and in their downstream targets, clearly have implications on the functioning of this pathway and the resulting phenotype.

Disorders of sex development (DSD) are defined as any congenital condition in which the development of chromosomal, gonadal, or anatomical sex is atypical [Hughes, 2008]. These disorders are further divided into three categories: (1) sex chromosome DSD; (2) 46,XY DSD; and (3) 46,XX DSD [Hughes, 2008]. 46,XY gonadal dysgenesis occurs in the range of 1 in 3,000 births [Camerino

Conflict of interest: none.

*Correspondence to:

Catherine E. Keegan, M.D., Ph.D., 3520 MSRB I, SPC 5652, 1150 W.

Medical Center Drive, Ann Arbor, MI 48109.

E-mail: keeganc@med.umich.edu

Article first published online in Wiley Online Library

(wileyonlinelibrary.com): 3 July 2013

DOI 10.1002/ajmg.a.36018 
et al., 2006]. Of these patients, $10-15 \%$ have a mutation in $S R Y$ and 10-15\% have a mutation in NR5A1 (SF1) [Hawkins et al., 1992; Philibert et al., 2010]. Other single gene causes have been identified in a few cases, and include mutations in WT1, SOX9, duplications of NROB1 (DAX1), and 1p duplications containing WNT4. Cytogenetically visible aberrations have been known to cause gonadal dysgenesis in a number of instances as well, with the areas $2 q, 9 p$, and 10q identified [Ostrer, 2004].

Partial monosomy for the distal segment of 9p (OMIM \#158170), initially described by Alfi et al. [1973], results in a phenotype of trigonocephaly, minor anomalies, and intellectual disability. Ambiguous genitalia are estimated to be present in up to $70 \%$ of patients with partial 9p monosomy [De Grouchy and Turleau, 1982; Schinzel, 2001]. The critical interval for 46,XY complete gonadal dysgenesis has been localized between 9p24.3 and 9pter [Flejter et al., 1998; Guioli et al., 1998]. Further work has identified DMRT1 to be the likely causative gene responsible for 46, $\mathrm{XY}$ complete gonadal dysgenesis in affected patients. Small intragenic DMRT1 deletions have also been associated with 46,XY complete gonadal dysgenesis although point mutations were not identified in DMRT1 when 46,XY female patients were evaluated [Raymond et al., 1999; Calvari et al., 2000; Vialard et al., 2002; Ledig et al., 2010, 2012].

Here, we present two patients with complete 46,XY gonadal dysgenesis found to have deletions of the distal segment of $9 \mathrm{p}$. Gonadectomy documented gonadoblastoma in both patients. We present their clinical description as well as their molecular workup that includes detailed characterization of copy number breakpoints by array $\mathrm{CGH}$. We review the literature regarding previously reported 46,XY patients with partial 9p monosomy and genital abnormalities, with special emphasis to $46, \mathrm{XY}$ complete gonadal dysgenesis and the incidence of gonadoblastoma. We note that a large number of partial $9 \mathrm{p}$ monosomy DSD patients have a secondary copy number variation (CNV) and suggest a possible twohit mechanism by which some $46, \mathrm{XY}$ patients with partial $9 \mathrm{p}$ monosomy present with DSD and others present with no sexrelated phenotype.

\section{CLINICAL REPORT}

\section{Patient 1}

Patient 1 has previously been reported elsewhere when she was 3 years old [McDonald et al., 1997; Flejter et al., 1998]. She was the first child of healthy, non-consanguineous parents, born at 42 weeks of gestation following a normal pregnancy. She had Apgar scores of 9 and 9 at 1 and $5 \mathrm{~min}$, respectively, with a birth weight of $4.48 \mathrm{~kg}$ (1-2 SD above the mean). No concerns were noted neonatally.

She was referred at 10 months for a family history of recurrent miscarriages and a known balanced translocation in a paternal uncle. At 10 months she was developmentally normal but around 17 months was noted to have delays in speech and gross motor development. At 3 years her expressive language was at approximately an 18-month level. She sat independently at age 12 months and walked at age 18 months. In all grades, she qualified for special education and physical therapy. At 15 years she was reading at approximately a second grade level (age 7 years). She graduated from high school with the assistance of special education. Currently, at age 20 years, she is attending classes through a transitional school, focusing on life-skills.

Cardiac evaluation as a neonate was performed for unknown reason and showed a bicuspid aortic valve and patent foramen ovale (PFO); electrocardiogram showed a complete right bundle branch block. Renal ultrasound and a pelvic ultrasound study at 3 years showed a normal uterus and vagina without identifiable gonads.

At age 3 her weight and height were between the 50th and 75th centiles with a head circumference greater than the 95 th centile. The patient was noted to have a single right palmar crease, bilateral 5th finger clinodactyly, mild metatarsus varus, and external female genitalia with no palpable gonads. Repeat evaluation at 19 years and 11 months of age revealed the patient's weight to be $100 \mathrm{~kg}$ (9597th centile) with a height of $173.5 \mathrm{~cm}$ (90-97th centile) and a BMI of 33.4. She required corrective lenses.

\section{Patient 2}

Patient 2 is a phenotypic female born at 33 weeks of gestation following a pregnancy complicated by preeclampsia and oligohydramnios. The patient's mother received no prenatal care until after 20 weeks gestation. She also reported use of marijuana and the prescription medications ondansetron, sertraline, bupropion, and fluconazole during the pregnancy. The patient's mother was 28 years old and had a history of developmental delay, cognitive impairment and depression with a known deletion of 9p24.1 and 22q11.21. Following delivery Apgar scores were 8 and 9 at 1 and $5 \mathrm{~min}$, respectively. Birth weight was $2.05 \mathrm{~kg}$ (58th centile), length $43.5 \mathrm{~cm}$ (38th centile), and head circumference $28 \mathrm{~cm}$ (50th centile for a 29.5-week gestation infant). An echocardiogram showed a PFO and small-to-moderate restrictive apical muscular ventricular septal defect (VSD). Hearing was normal. Congenital hypothyroidism is being managed with levothyroxine.

Results of cranial ultrasonography were normal. A pelvic ultrasound study showed a normal uterus; gonads were not visualized. On renal ultrasonography kidneys were normal but with significant left hydronephrosis suggestive of ureteropelvic junction (UPJ) obstruction, confirmed on diuretic renal scan. This was corrected at age 1 year.

The patient was developmentally delayed early on and required developmental services. At age 4 months, she was meeting all developmental milestones. She began walking independently at age 15-16 months. At 17 months, her expressive language development was equivalent to that of a 14-month-old but with advanced receptive language.

At 4 months the patient weighed $5.14 \mathrm{~kg}$ (5th centile) was $56.1 \mathrm{~cm}$ long (1st centile) and had a head circumference of $36.8 \mathrm{~cm}$ (50th centile for 1 month). At that time we noted a small nose, mild micrognathia and right occipital plagiocephaly. She had an easily reducible umbilical hernia, female external genitalia, transitional palmar crease on the right hand, mild head lag but had an otherwise normal neurologic status. At age 17 months weight was $8.92 \mathrm{~kg}$ ( $3 \mathrm{rd}$ centile), height $75.2 \mathrm{~cm}$ (8th centile), and head circumference $42 \mathrm{~cm}$ (50th centile for a 5-month old). Results of eye examination and hearing test at age 1 year were normal. 


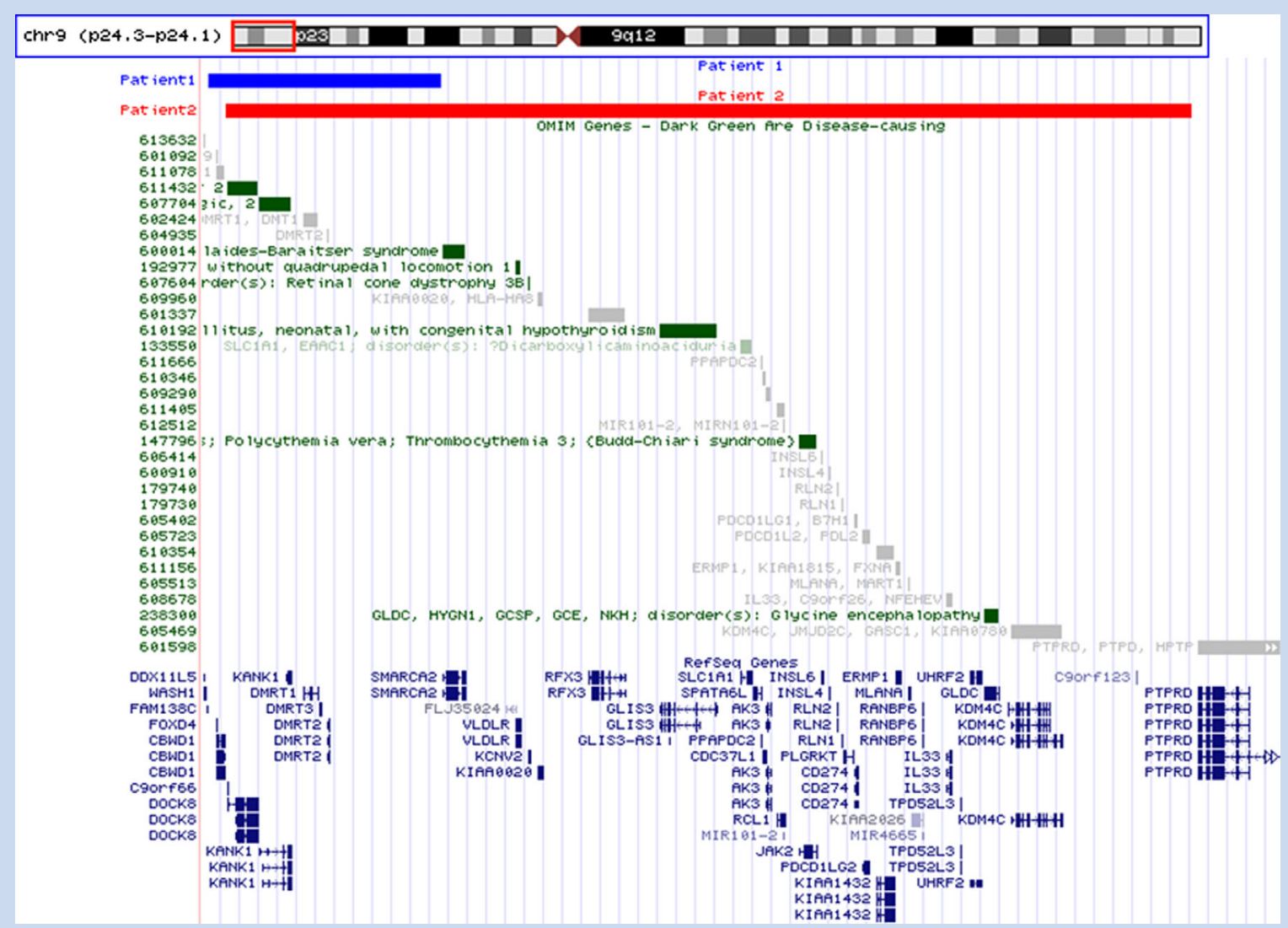

FIG. 1. Deleted region of chromosome 9 in Patients 1 and 2 shown in UCSC genome browser. The 9p haploinsufficient regions affecting Patients 1 and 2 are depicted in blue and red, respectively. OMIM and UCSC genes within the affected region are listed below deleted intervals.

\section{RESULTS}

\section{Patient 1}

At 10 months of age a karyotype obtained at the University of Utah showed a 46,XY,der(9)t $(8 ; 9)(\mathrm{p} 21 ; \mathrm{p} 24)$ unbalanced chromosome constitution with monosomy 9p24 and trisomy 8p21. At age 19 years, the boundaries of the deleted and duplicated regions were refined by microarray methods which identified a $25.3-\mathrm{Mb}$ single copy duplication of 8p23.3p21.2 (176,818-25,510,851; hg 19) and a 2.0-Mb single copy deletion of 9p24.3 (46,587-1,994,144; hg 19) (Fig. 1). Father had a balanced translocation $46, X Y, t(8,9)(p 21$; p24).

Given the increased incidence of gonadal malignancy in patients with gonadal dysgenesis, the patient underwent gonadectomy at age 3 years. Laparoscopic evaluation at that time showed the presence of a uterus and Fallopian tubes. Gonads were ovoid, white, firm and measured $2.5 \times 0.6 \times 0.8 \mathrm{~cm}$. Both gonads had nearly identical histologic structure: They were dysgenic without ovarian follicles or seminiferous tubules. Cellular nests contained two cell types, large and round cells with clear cytoplasm and a large round nucleus and smaller comma-shaped cells. The histologic diagnosis was: gonadoblastoma.

\section{Patient 2}

The patient's mother had a known history of 9p24.1 deletion and 22q11.21 deletion. A maternal chromosomal microarray study refined the boundaries of the 9p24.1 (194,104-8,256,492; hg 18) and 22q11.21 (18,989,547-19,835,417; hg 18) deletions measuring $8.3 \mathrm{Mb}$ and $846 \mathrm{~kb}$ in size, respectively (Fig. 1). Amniocentesis of Patient 2's mother showed 45,X/46,XY mosaicism and the 9p deletion. Following delivery, metaphase FISH analysis of 15 cells identified the 22q11.21 deletion as well in Patient 2. Postnatal karyotype also confirmed the maternally inherited deletion of 9p24. Her karyotype was denoted as 46,XY,del(9)(p24.1)mat.ishdel(22) (q11.21q11.21)(b135h6-). Given the prenatal mosaicism, 30 metaphase cells were analyzed postnatally and showed low level mosaicism for a 45,X cell population. Of 500 interphase cells, FISH probes specific to $\mathrm{X}$ and $\mathrm{Y}$ centromeres showed $5.6 \%$ of the cells had a $45, \mathrm{X}$ constitution and $94.4 \%$ of the cells had a $46, \mathrm{XY}$ constitution.

Given the increased risk of gonadal malignancy, the patient underwent gonadectomy at 1 year of age. Laparoscopic evaluation showed a normal uterus and Fallopian tubes. Both gonads were "streak," measuring $1.4 \times 0.5 \times 0.3 \mathrm{~cm}$ and $0.9 \times 0.3 \times 0.3 \mathrm{~cm}$ (Fig. 2A). Grossly no tumor nodules were recognized. Microscopi- 
A

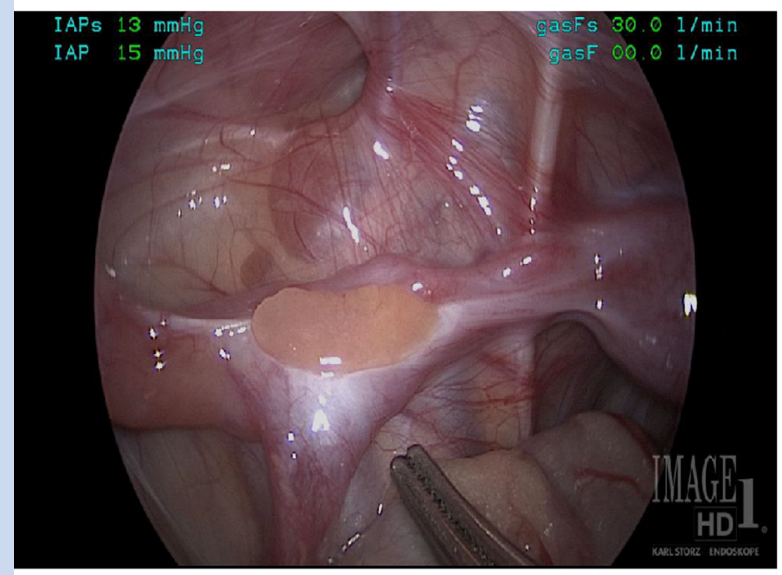

B

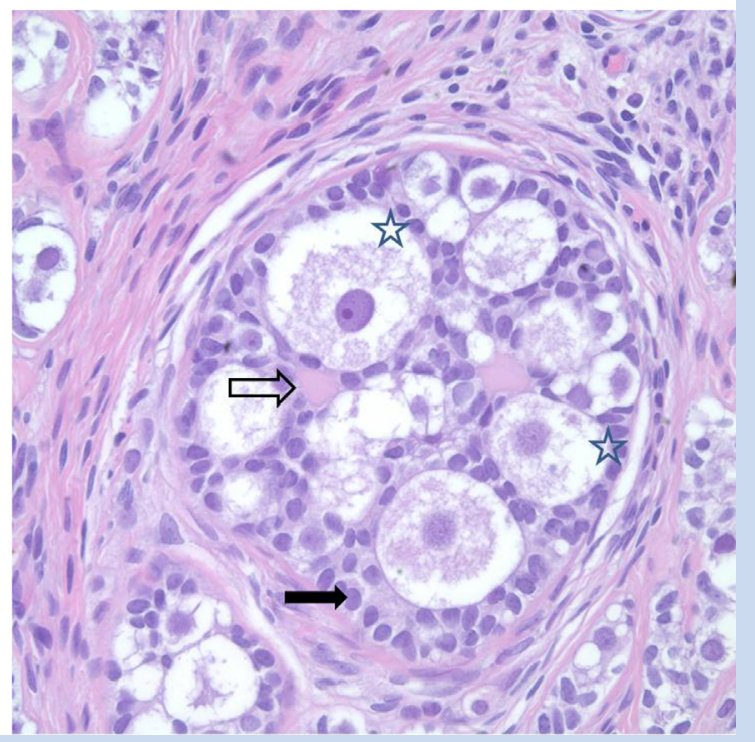

FIG. 2. Intraoperative and pathology images of Patient 2. A: Intraoperative photograph showing streak gonad. B: Gonadoblastoma focus containing large germ cells (star), small dark stromal cells (dark arrow), and eosinophilic hyaline bodies (open arrow).

cally, both gonads showed ovarian stroma with small foci of gonadoblastoma with microcalcifications (Fig. 2B). These foci contained nests of large germ cells with clear cytoplasm surrounded by smaller cells with dark hyperchromatic nuclei consistent with stromal sex cord type cells. Eosinophilic hyaline bodies composed of basement membrane material were also noted in the nests. No follicle formation or testicular differentiation was noted. No invasive tumor was seen. Cytogenetic analysis of the gonadal tissue showed mosaicism for 45,X and 46,XY cell lines and the previously identified deletion of 9p24.1. Following metaphase and interphase FISH analysis, shown in Figure 3, it was determined that one gonad contained 46\% 45,X cells and 54\% 46,XY cells with the other having $67 \% 45$,X cells and $33 \% 46, X Y$ cells.

\section{DISCUSSION}

DSD are a clinically and causally heterogeneous group of disorders. In patients with 46,XY complete gonadal dysgenesis, a cause is identified in less than half of the cases. Up to $20-30 \%$ of these are attributed to $S R Y$ and $S F 1$ mutations with other single gene causes contributing only a small proportion of the remainder [Hawkins et al., 1992; Philibert et al., 2010]. Array-comparative genomic hybridization has allowed clinicians to detect CNVs not visible cytogenetically and also allowed refinement of those previously detected karyotype aberrations. Ledig et al. [2010] estimated that the cause of $25 \%$ of syndromic and $5.6 \%$ of non-syndromic gonadal dysgenesis could be identified by array CGH. Hemizygosity of the distal segment of 9p is known to cause 46,XY gonadal dysgenesis and other milder genital phenotypes including ambiguous genitalia, hypospadias and cryptorchidism. Here we present two patients with a diagnosis of 46,XY complete gonadal dysgenesis found to have partial monosomy for $9 \mathrm{p}$ and other cytogenetic abnormalities.

The two patients reported here presented with classic findings consistent with complete 46,XY gonadal dysgenesis. Patient 1 was reported previously, with further molecular studies performed following the initial report [McDonald et al., 1997; Flejter et al., 1998]. As recommended by Flejter et al. [1998] the data reported here further characterize the deletion and duplication boundaries of this patient [Huret et al., 1988; Flejter et al., 1998; Muroya et al., 2000; Swinkels et al., 2008]. The patient is also trisomic for approximately $25 \mathrm{Mb}$ of the short arm of chromosome 8 . The phenotypic consequences of this aberration are unknown at this time. Of note, GATA4 is within the duplicated region. Loss-offunction mutations and haploinsufficiency of GATA4 has implications in sexual and cardiac development, with mutations causing 46,XY gonadal dysgenesis and heart septation defects, respectively [Reamon-Buettner and Borlak, 2005; Lourenço et al., 2011]. There has been debate as to whether GATA4 duplication results in cardiac defects, but it remains an important consideration given the patient's bicuspid aortic valve [Yu et al., 2011]. No gain-of-function mutations or duplications of GATA4 have been reported to cause gonadal dysgenesis or genital abnormalities, but patients with $8 \mathrm{p}$ duplications that include GATA4 have presented with hypospadias [Yu et al., 2010, 2011]. The large number of genes involved makes an exact genotype-phenotype correlation difficult to establish.

Patient 2 also presented with findings of complete gonadal dysgenesis. Her mosaic karyotype contained both 45,X and 46, $\mathrm{XY}$ cell lines. The external phenotype in patients with $45, \mathrm{X} / 46, \mathrm{XY}$ mosaicism can include normal male or female genitalia or ambiguous genitalia with gonadal pathology also variable, ranging from 


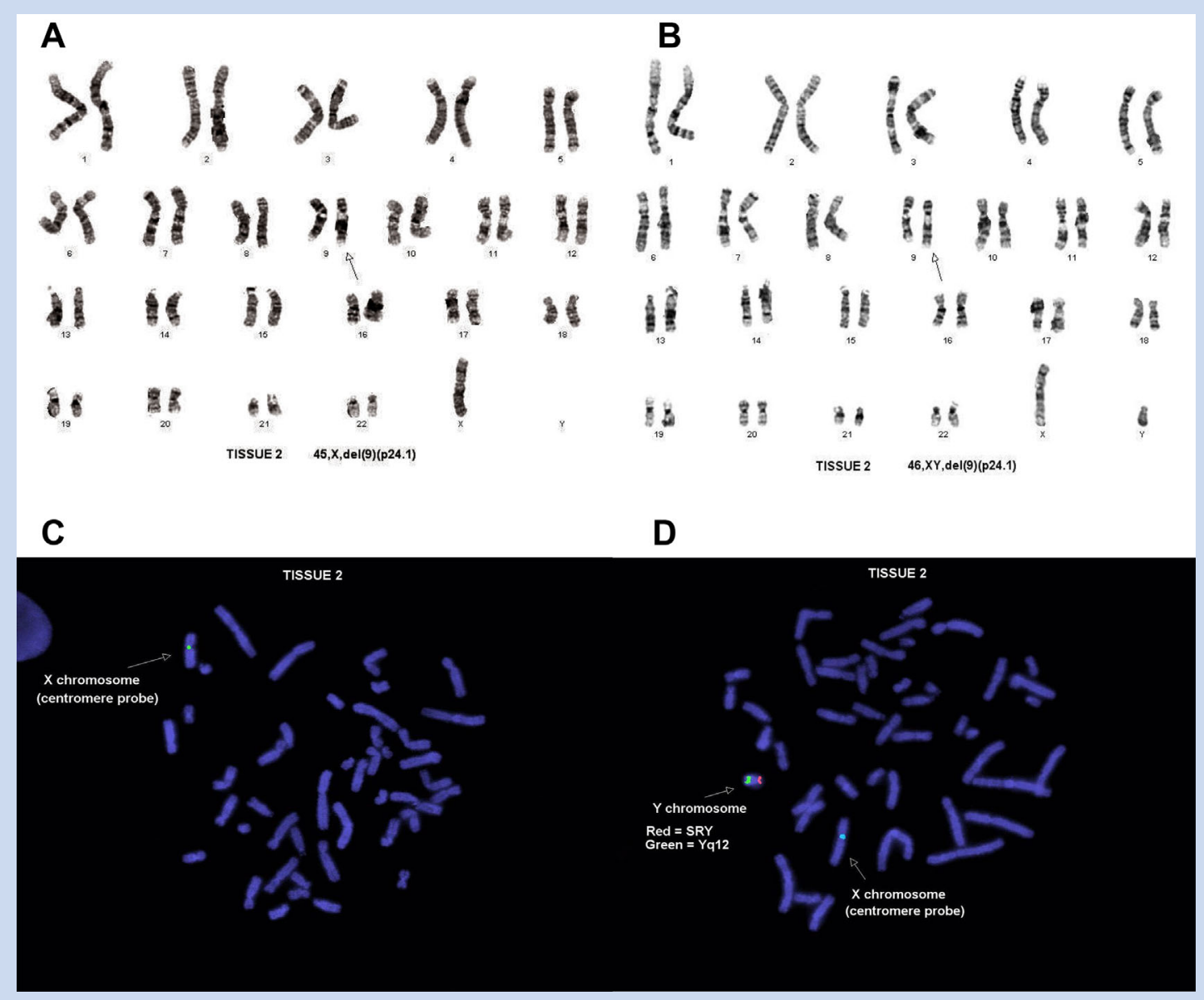

FIG. 3. Cytogenetic results of Patient 2's mosaic gonadal tissue using X chromosome centromeric (green), SRY (red), and Yq12 (green] probes of gonadal tissue. A: 45,X,del[9](p24.1) karyotype. B: 46,XY,del(9)(p24.1) karyotype of gonadal tissue 2. C: FISH analysis showing only one $X$ chromosome signal and absent hybridization of $Y$ chromosome probes. D: FISH analysis confirming mosaicism with hybridization of both $X$ and $Y$ probes.

apparently normal testes to dysgenetic gonads [Farrugia et al., 2013; Tosson et al., 2012]. Similar to Patient 2, individuals with 45,X/46, $\mathrm{XY}$ mosaicism can have significant differences in the percentage of 45, $\mathrm{X}$ and 46,XY cell lines present in different tissues [Tosson et al., 2012]. This has clear implications in gonadal development, with the elevated percentage of 45,X cells (67\%) present in Patient 2 's gonadal tissue likely contributing to their dysgenetic development. Determining the exact contribution that each cytogenetic aberration (partial 9p monosomy and the 45,X cell line) has on Patient 2's phenotype is difficult to establish. The patient will require management for Turner syndrome as she grows.

Patient 2 also inherited an $846 \mathrm{~kb}$ deletion of 22q11.21 from her mother. This deletion lies within the distal half of the common $3 \mathrm{Mb}$ deletion associated with DiGeorge syndrome (OMIM $\# 18440$ ) and velocardiofacial syndrome (VCFS; OMIM \#192430). The proximal region of the long arm of chromosome 22 has a large number of low copy repeats that increase the risk of rearrangements caused by non-allelic homologous recombination. The most common rearrangement, seen in DiGeorge syndrome/
VCFS, occurs as a result of non-allelic homologous recombination between low copy repeats 2 and 4, as defined by Edelmann et al. [1999] and McDermid and Morrow [2002]. Patients have been described with deletions of the surrounding genomic area [GarciaMiñaur et al., 2002; Rauch et al., 2005; Ogilvie et al., 2009; Breckpot et al., 2012]. Our patient's deletion contains 19 genes including three OMIM disease genes (ZNF74, HCF2, and SNAP29) but does not include $T B X 1$. It is nearly identical to the deletions reported by Garcia-Miñaur et al. [2002] and Rauch et al. [2005], and lies between low copy repeat 3 and low copy repeat 4 . The patient reported by Garcia-Miñaur et al. [2002], a male who inherited his deletion from an asymptomatic father, had Tetralogy of Fallot, microcephaly and minor anomalies. Rauch et al. [2005] reported on a patient with a similar deletion who also presented with congenital heart disease (CHD), mild hypotonia, frequent infections and facial features consistent with mild DiGeorge syndrome. This deletion may provide a partial explanation of the VSD in Patient 2 with haploinsufficiency for CRKL (within the deleted segment) suggested as a candidate gene responsible for the CHD in these patients 
[Breckpot et al., 2012]. 46,XY gonadal dysgenesis has not been reported in these patients, but two patients have been reported with 46,XX testicular DSD who were found to have the DiGeorge deletion [Phelan et al., 2002; Erickson et al., 2003]. Similar to the presence of the $45, \mathrm{X}$ cell line, this deletion makes assigning responsibility to any one causative cytogenetic aberration difficult.

Both patients presented with $9 \mathrm{p}$ monsomy as well as other significant chromosomal abnormalities that make establishing an exact genotype-phenotype relationship difficult. To gain additional insights, we reviewed the literature and identified previous reports of partial $9 \mathrm{p}$ monosomy causing haploinsufficiency of DMRT1, the leading candidate gene for 46,XY complete gonadal dysgenesis in these patients (see below). Specific emphasis was paid to patients with 46,XY karyotypes and any genital-related phenotypic abnormalities (Table I). The reported genital phenotypes ranged from complete gonadal dysgenesis to cryptorchidism, hypospadias, and micropenis. Though Table I is limited to those patients with genital abnormalities, multiple 46 ,XY patients with no abnormal genital phenotype or complete gonadal dysgenesis have been described with monosomy for near-identical segments of $9 p$ (Table II). This is in contrast to a number of patients with complete or partial 46,XY gonadal dysgenesis found to have small intragenic deletions in DMRT1 [Ledig et al., 2010, 2012].

Review of Table I shows that $60 \%$ (43/72) of those patients with genital abnormalities and/or complete gonadal dysgenesis have at least one additional CNV/karyotype abnormality besides monosomy for a portion of $9 \mathrm{p}$. Most of these are trisomies caused by an unbalanced translocation. Given the variable penetrance and expressivity of the genital phenotype, this may suggest a second hit is needed for the 46,XY complete gonadal dysgenesis and/or genital abnormalities to develop. Huret et al. [1988] evaluated 80 cases of partial 9p monosomy and compared those with other unbalanced segments (41 cases) with those containing only partial 9p monosomy (39 cases). They found $42 \%$ of both groups presented with external genitalia abnormalities. It should be noted though that both groups included both 46,XY and 46,XX patients. Given that partial 9p monosomy, especially DMRT1 haploinsufficiency, affects 46,XX individuals much less significantly (no testicular DSD/ gonadal dysgenesis or genitalia ambiguity) than those with 46 , XY karyotypes, the data in Table I should prove more useful when considering the genotype-phenotype relationships of partial $9 p$ monosomy. Comparing the patients in Table I to those patients without external genital abnormalities (Table II) reveals statistically significant support for a two-hit hypothesis as $81 \%(13 / 16)$ of those patients with no genital phenotypes have only one noted $\mathrm{CNV} /$ cytogenetic abnormality (Fisher's exact test, $P=0.0047$ ). Further comparison of both groups of patients reveals that the three patients with no genital abnormalities and a second hit have similar additional CNVs to three patients listed in Table I (trisomy for portions of $6 p, 10 q$, and $20 p)$. This suggests further variable expressivity or incomplete penetrance of these duplicated regions versus an unknown alternative locus contributing to the genital phenotype in the affected patients. It should also be mentioned that a significant percentage of the patients evaluated have only had karyotype analysis. Chromosomal microarray would likely identify the presence of additional copy number abnormalities undetectable by cytogenetic techniques. A potential reporting bias should also be considered as patients with a more severe phenotype and/or multiple copy number abnormalities are more likely to be reported. Regardless though, given the significant differences between both groups, further evaluation of a two-hit mechanism is warranted.

This two-hit hypothesis is similar to the previously suggested second-hit models involving other developmental abnormalities including a cardiac phenotype in GATA4 duplications [Girirajan et al., 2010; Yu et al., 2011; Lupski, 2012]. Though chromosomal duplications, which represent most of the second-hits in our patients, are better tolerated when compared to deletions, duplication of DAX1 can lead to 46,XY complete gonadal dysgenesis [Barbaro et al., 2007], and dosage sensitivity is well described in mouse sex reversal [Bouma et al., 2007; Buaas et al., 2009; Correa et al., 2012]. Overall, this may suggest a role for other duplicated regions and dosage-sensitive genes in providing the second-hit responsible for the gonadal dysgenesis phenotype in these patients. Review of the genomic regions reported as second hits in Table I failed to identify any strong candidate genes that could be implicated in the abnormal genital phenotype. Although there are genes that have been implicated in abnormal sex development within duplicated regions of the $9 \mathrm{p}$ monosomy patients, including CYP11A and SRD5A2, the genital abnormalities are associated with loss of function rather than gain of function.

As previously mentioned, DMRT1 is the gene likely responsible for gonadal dysgenesis in a subset of $9 \mathrm{p}$ monosomy patients. Localized to the 9p24.3 region are three DMRT (DoublesexMab3-Related Transcription factor 1-3) genes. These genes were initially identified as strong candidate genes for 46,XY complete gonadal dysgenesis based on their Caenorhabditis elegans and Drosophila melanogaster homologues' role in sexual development [Raymond et al., 1998, 1999]. DMRT genes contain a DNA-binding motif domain, a zinc containing DNA-binding module [Zhu et al., 2000]. In mammals, DMRT1 is expressed only in the gonad and following sex determination, only in the testis [Raymond et al., 1998; Matson and Zarkower, 2012]. DMRT1-null male mice have normal external genitalia with functional Sertoli cells, but have hypoplastic testes, disorganized seminiferous tubules and lack germ cells [Raymond et al., 2000]. Heterozygous males are phenotypically normal with normal testes and retained fertility [Raymond et al., 2000]. However, in homozygous null male mice, at 2 weeks following birth, the Sertoli cell expression pattern changes; there is decreased expression of SOX9, increased expression of FOXL2, and overall reprogramming of Sertoli cells into a granulosalike cell type [Matson et al., 2011]. This, and data regarding the function of granulosa cells, suggests that following determination and differentiation, both Sertoli and granulosa cells require the presence of certain proteins to maintain their identity and function [Matson and Zarkower, 2012]. This principle, termed sex maintenance, is achieved in males through the function of DMRT1, and in females through FOXL2 [Uhlenhaut et al., 2009; Matson et al., 2011].

Review of Patient 2's history reveals the presence of congenital hypothyroidism diagnosed on newborn screening. Though there are multiple genetic causes of congenital hypothyroidism, it is interesting to note that Patient 2 is haploinsufficient for GLIS3, which lies within the deleted 9p interval. GLIS3 loss-of-function mutations cause an autosomal recessive syndrome termed Neona- 


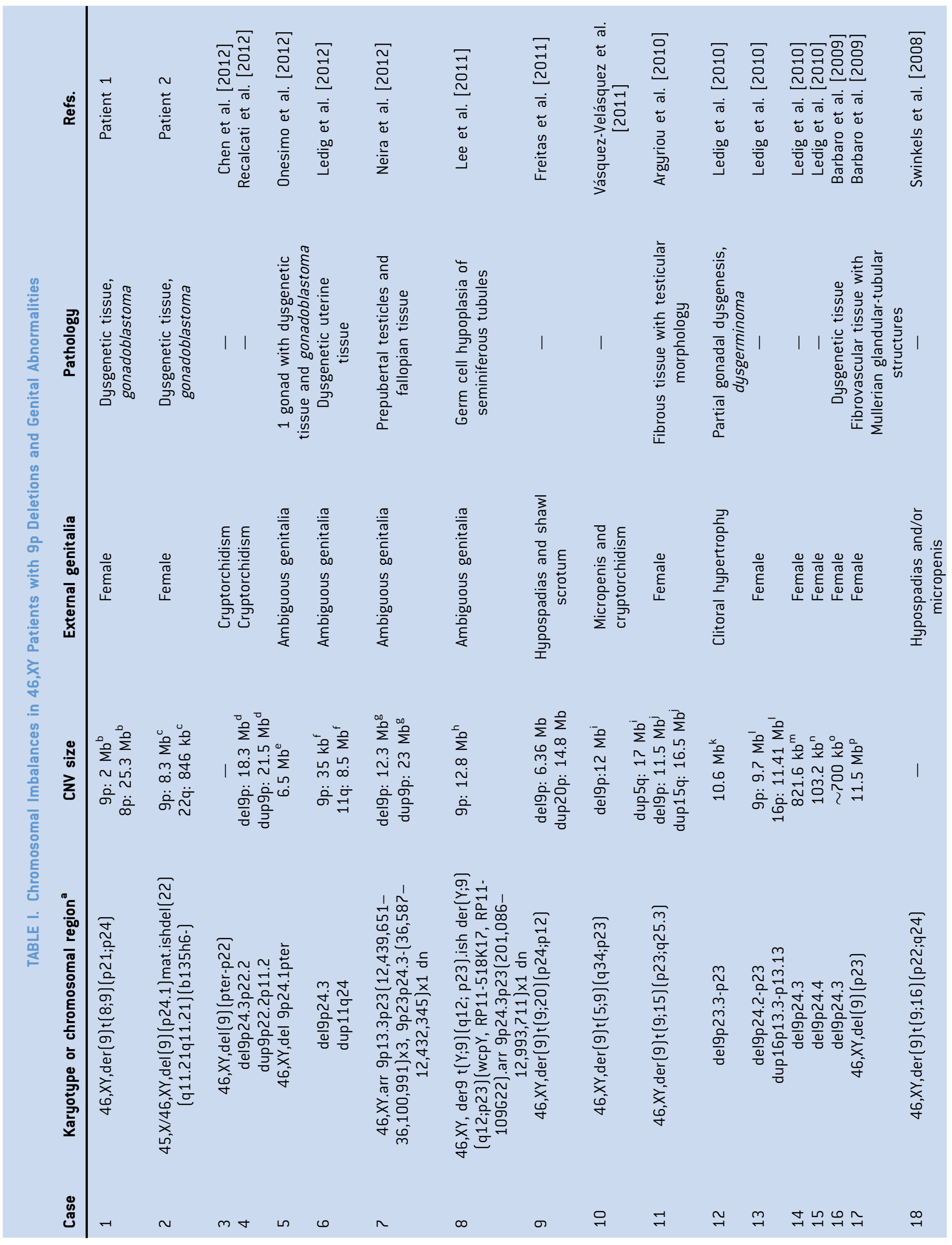




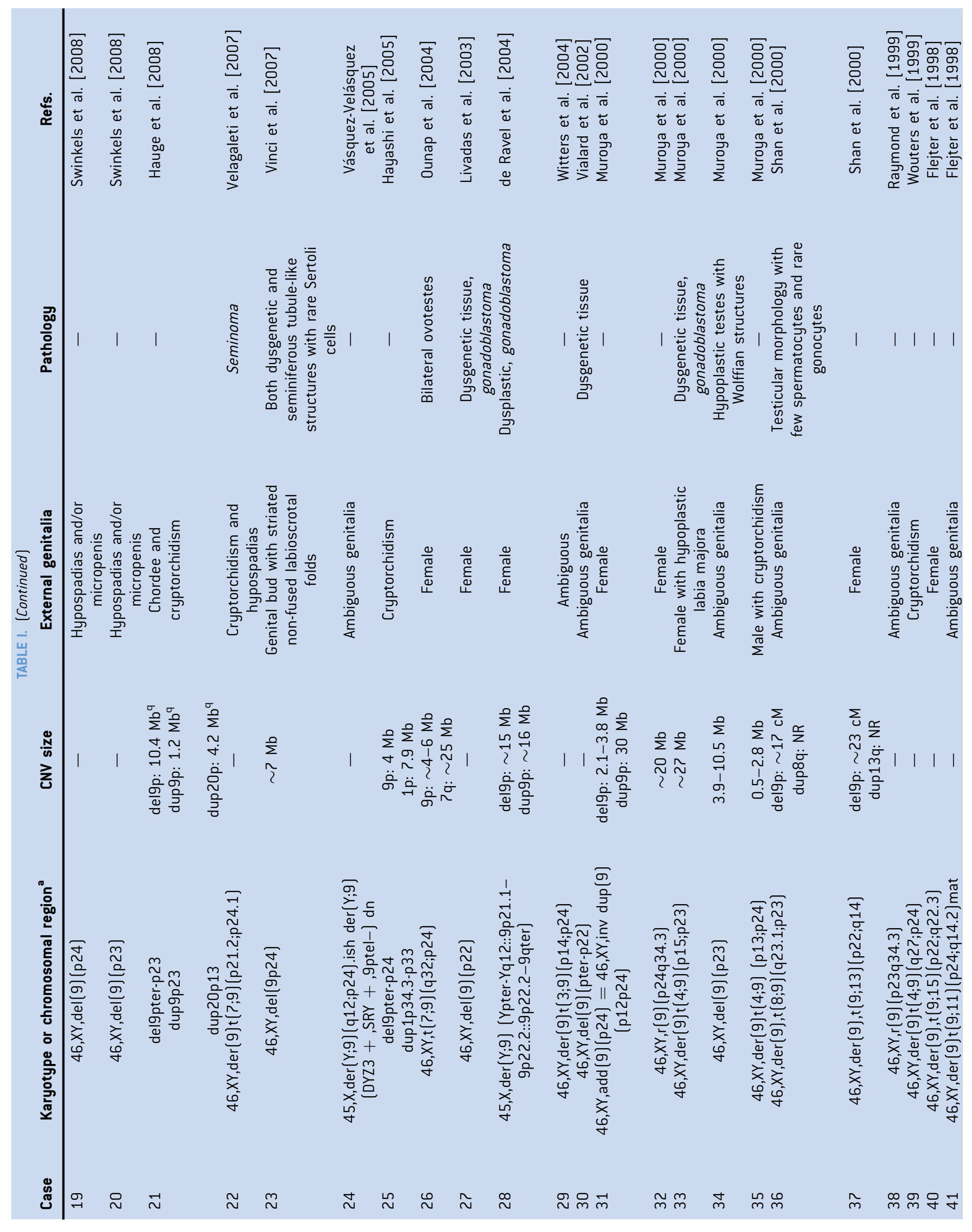




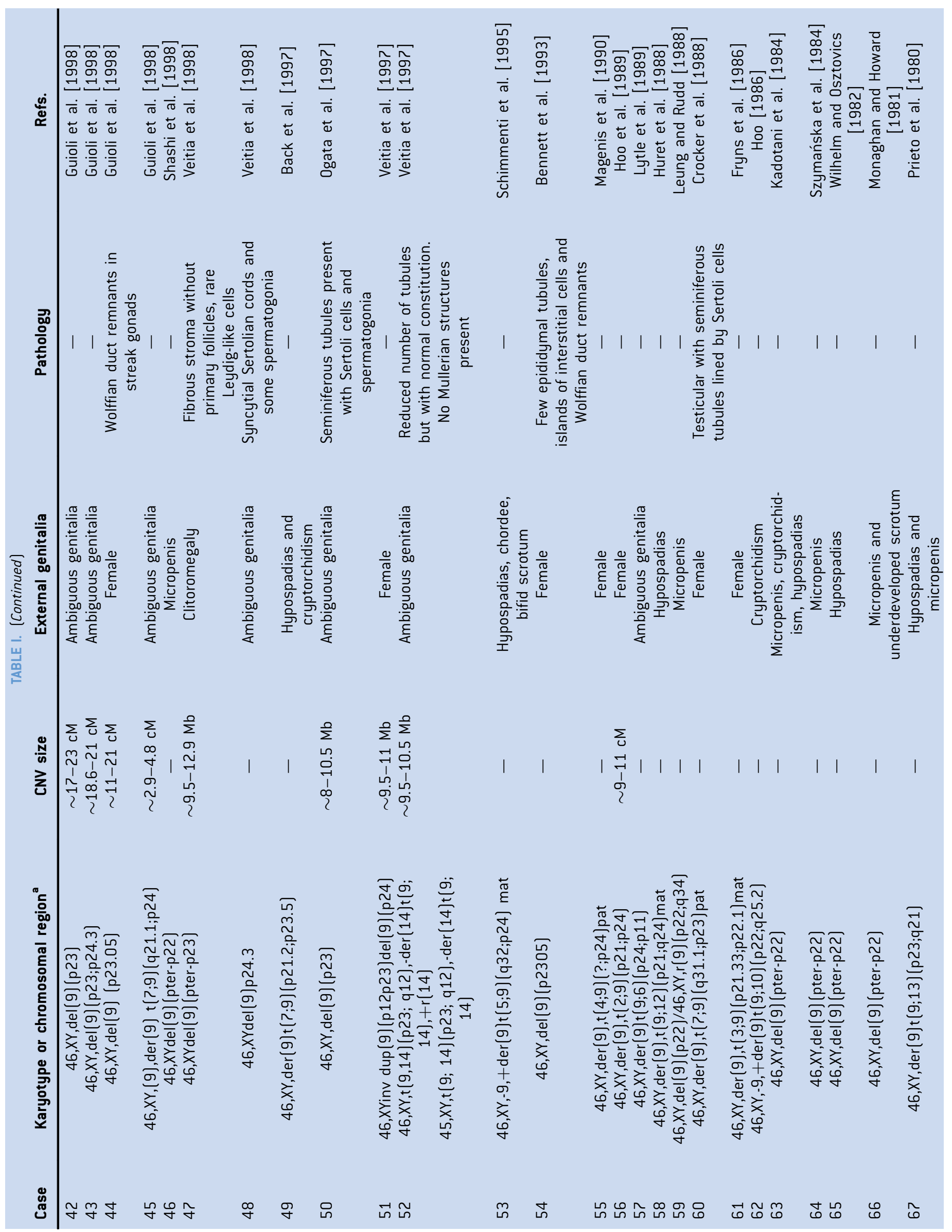




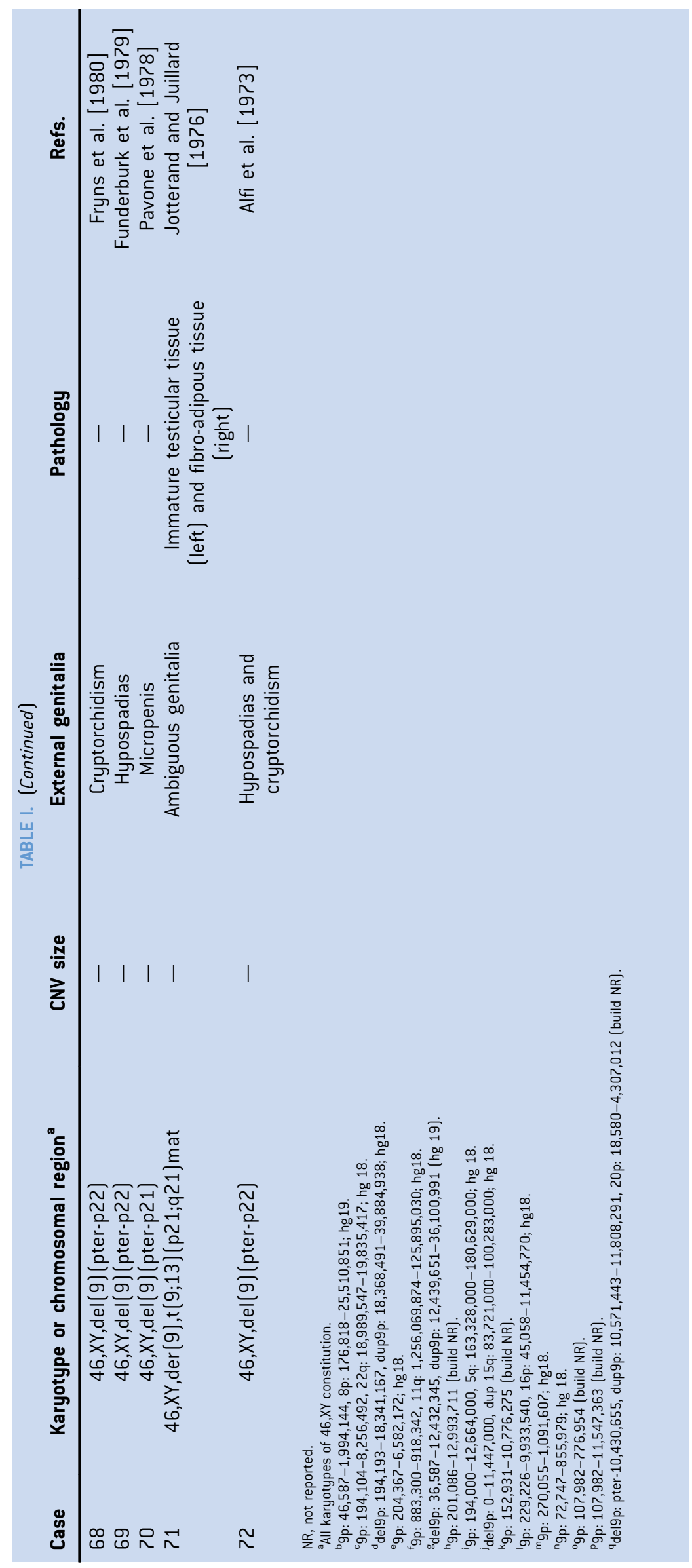


TABLE II. Chromosomal Imbalances in 46,XY Patients With 9p Deletions and No Genital Abnormalities

1

2

3

4

5

6

7

8

9

10

11

12

13

14

15

16

\section{Case}

Karyotype or chromosomal region ${ }^{a}$

del9pter-p22 dup10q26-qter

del9pter-p23

46,XY, del(9) (p24.3)

del9pter-p23

dup20pter-p12.1

del9pter-p22.3

46,XY,del(9) (pter-p22)

46,XY,del(9) (qter-p220

46,XY,del(9) (qter-p2304)

46,XY, der(9)t (6:9) (p211;p24)

46,XY,del(9) (pter-p22)

46,XY,del(9) (pter-p12)

$46, X Y$, del(9) (pter-p22)

46,XY,del(9) (pter-p12)

46,XY, del(9) (pter-p22)

46,XY,del(9) (pter-p22)

46,XY,del(9)(pter-p21)
CNV size

Refs.

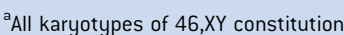

b: pter-1,167,143-1,233,178 (build NR)

\begin{tabular}{|c|c|}
\hline- & Akbas et al. [2011] \\
\hline $11.1 \mathrm{Mb}$ & Shimojima and Yamamoto [2009 \\
\hline $1.17-1.23 \mathrm{Mb}^{\mathrm{b}}$ & Hauge et al. [2008] (Case 3) \\
\hline $\begin{array}{l}\text { del9p: } 10 \mathrm{Mb} \\
\text { dup20p. } 14 \mathrm{Mb}\end{array}$ & Hauge et al. [2008] (Case9) \\
\hline$\sim 15 \mathrm{Mb}$ & Swinkels et al. [2008] (Case 8) \\
\hline- & Huret et al. [1988] (Case 2) \\
\hline - & Boby et al. [1994] \\
\hline - & Taylor et al. [1991] \\
\hline - & Eden et al. [1985] \\
\hline - & loan et al. [1985] \\
\hline - & Young et al. [1983] \\
\hline - & Bricarelli et al. [1981] \\
\hline - & Hernandez et al. [1979] \\
\hline- & Nielsen et al. [1977] \\
\hline- & Alfi et al. [1976] \\
\hline - & Serville et al. [1976] \\
\hline
\end{tabular}

tal diabetes mellitus with congenital hypothyroidism (OMIM \#610199) [Senée et al., 2006]. This condition has been seen in consanguineous Saudia Arabian families and can include hepatic fibrosis, congenital glaucoma and polycystic kidneys. Though Patient 2 has loss of only one copy of the gene, it is possible that haploinsufficiency results in the congenital hypothyroidism but none of the other features that are part of the condition. Multiple other patients have been reported with partial 9p monosomy and hypothyroidism [Ioan et al., 1985; Kozma et al., 2000; Velagaleti et al., 2008]. Review of Patient 1's deleted 9p interval shows GLIS3 not to be deleted. It is also possible that the deletion of GLIS3 in Patient 2 uncovered an autosomal recessive mechanism leading to her congenital hypothyroidism, leading to speculation that she may carry a deleterious mutation of her other GLIS3 allele. Further testing would be required to prove this hypothesis. Regardless, we recommend evaluation for hypothyroidism in patients with partial 9p monosomy, especially if GLIS3 is within the deleted interval.

Patients with DSD, specifically those with dysgenetic gonads and/or hypovirilization, have an increased risk of type II germ cell tumors [Looijenga et al., 2010]. Gonadoblastomas are estimated to occur in up to $30 \%$ of $46, \mathrm{XY}$ patients with dysgenetic gonads [Sultana et al., 1995]. The presence of Y chromosome material has been implicated in the oncogenesis in these patients, with the locus mapped to the Y centromeric region [Page, 1987]. TSPY has arisen as the leading candidate for the responsible gene [Lau, 1999]. Given this increased risk, both of the patients reported here underwent gonadectomy with pathology showing the presence of dysgenetic gonads and gonadoblastoma. Additional immunohistochemical stains were not performed on our two patients' samples because both lacked identifiable seminiferous tubules, making specific staining to differentiate delayed germ cell maturation from intratubular germ cell neoplasia unnecessary. Review of Table I shows that multiple patients reported in the past developed gonadoblastoma as well. Livadas et al. [2003] previously reviewed the literature as it pertained to gonadoblastoma in patients with $9 p$ deletions and other 46,XY complete gonadal dysgenesis loci. Review of Table I shows that of those patients with 46,XY karyotypes, complete gonadal dysgenesis and partial 9p monosomy, $11 \%(8 / 72)$ developed a gonadal malignancy. If only those patients with pathology data are considered, this percentage increases to $30 \%$ $(8 / 27)$. It is also important to note that most gonadal malignancies occurred in patients with complete gonadal dysgenesis (with the exception of Cases 3 and 8 who presented with ambiguous genitalia and clitoral hypertrophy, respectively). This supports the recommendation that gonadectomy be performed in patients with gonadal dysgenesis, especially those with partial 9p monosomy. Specific recommendations regarding gonadectomy and surveillance of 9p monosomic individuals with less severe genital phenotypes are difficult to make at this time given that the natural history of this cohort is currently unknown. Empirically, for these patients we recommend annual testicular examinations and consideration of scrotal ultrasound until adult age. Clinicians should have a low threshold for biopsy if suspicious findings are identified.

While the presence of TSPY can contribute to the increased risk of malignancy in these patients, loss of DMRT1 activity has also been linked to an increased risk of cancer given its proposed tumor suppressor properties [Krentz et al., 2009]. Krentz et al. [2009] reported an increased incidence of testicular teratoma (Type I germ cell tumor) with loss of DMRT1 in the male mice of the 129Sv strain. This incidence was noted to be around $90 \%$ in homozygous null 
mutants and 4\% in heterozygous mice with no noted increased tumor incidence in female mice. This increased teratoma risk was shown to result from a disruption of cell cycle pluripotency and cell cycle control [Krentz et al., 2009]. Genome wide association studies have also shown an increased susceptibility to testicular germ cell cancer in or around DMRT1 [Turnbull et al., 2010; Kanetsky et al., 2011; Kratz et al., 2011]. It remains difficult to determine the exact oncogenic contribution that haploinsufficiency for $D M R T 1$ has, but further evaluation of this evolutionarily conserved pathway is clearly needed.

In conclusion, we report two patients with 46,XY complete gonadal dysgenesis caused by partial $9 \mathrm{p}$ monosomy. Both patients underwent gonadectomy, which revealed the presence of gonadoblastoma. The deletion breakpoints of Patient 1 , who has previously been reported, were further characterized. Both patients' deletions resulted in DMRT1 haploinsufficiency, which is likely contributing to their gonadal dysgenesis. Review of the literature shows that haploinsufficiency for DMRT1 results in gonadal dysgenesis and abnormal sex development with variable penetrance and expressivity. We suggest this variability may be due to the presence of a second-hit (CNV or other molecular mechanism), which may be needed for subsequent abnormal sex development. Gonadoblastoma was also present in a significant percentage of patients with partial 9p monosomy, specifically those with gonadal dysgenesis, further supporting the recommendation that gonadectomy be performed in these patients. Further investigation will hopefully elucidate the relationship between DMRT1 loss-of-function/haploinsufficiency and oncogenesis.

\section{REFERENCES}

Akbas E, Polat S, Karakas-Celik S, Altintas ZM, Yildirim M, Yilgor E. 2011. A severely mental and motor retarded boy with monosomy 9 pter $->$ p22 trisomy 10q26->qter due to paternal reciprocal translocation 46,XY,t (9;10)(p23;q26). Genet Couns 22:417-423.

Alfi O, Donnell GN, Crandall BF, Derencsenyi A, Menon R. 1973. Deletion of the short arm of chromosome \#9 (46,9p-): A new deletion syndrome. Ann Génét 16:17-22.

Alfi OS, Donnell GN, Allderdice PW, Derencsenyi A. 1976. The 9psyndrome. Ann Génét 19:11-16.

Argyriou L, Hiort O, Meinecke P, Wünsch L, Volleth M, Hinrichs F, Caliebe A, Gillessen-Kaesbach G. 2010. A de novo unbalanced translocation leading to partial monosomy 9p23-pter and partial trisomy $15 \mathrm{q} 25.3$ qter associated with 46,XY complete gonadal dysgenesis, tall stature and mental retardation. Clin Dysmorphol 19:190-194.

Back E, Jung C, Zeitler S, Schempp W. 1997. De novo duplication of 7 pter->p21.2 and deletion of 9pter->p23.5: Clinical and cytogenetic diagnosis. Clin Genet 51:56-60.

Barbaro M, Oscarson M, Schoumans J, Staaf J, Ivarsson SA, Wedell A. 2007. Isolated 46,XY gonadal dysgenesis in two sisters caused by a Xp21.2 interstitial duplication containing the DAX1 gene. J Clin Endocrinol Metab 92:3305-3313

Barbaro M, Balsamo A, Anderlid BM, Myhre AG, Gennari M, Nicoletti A, Pittalis MC, Oscarson M, Wedell A. 2009. Characterization of deletions at $9 p$ affecting candidate regions for sex reversal and deletion $9 p$ syndrome by MLPA. Eur J Med Genet 17:1439-1447.

Bennett CP, Docherty Z, Robb SA, Ramani P, Hawkins JR, Grant D. 1993. Deletion 9p and sex reversal. J Med Genet 30:518-520.
Boby J, Karande SC, Lahiri KR, Jain MK, Kanade S. 1994. 9p- syndrome. J Postgrad Med 40:40-41.

Bouma GJ, Washburn LL, Albrecht KH, Eicher EM. 2007. Correct dosage of Fog2 and Gata4 transcription factors is critical for fetal testis development in mice. Proc Natl Acad Sci USA 104:1499414999.

Breckpot J, Thienpont B, Bauters M, Tranchevent LC, Gewillig M, Allegaert K, Vermeesch JR, Moreau Y, Devriendt K. 2012. Congenital heart defects in a novel recurrent 22q11.2 deletion harboring the genes CRKL and MAPK1. Am J Med Genet Part A 158A:574-580.

Bricarelli FD, Fraccaro M, Lindsten J, Müller U, Baggio P, Carbone LD, Hjerpe A, Lindgren F, Mayerová A, Ringertz H, Ritzén EM, Rovetta DC, Sicchero C, Wolf U. 1981. Sex-reversed XY females with campomelic dysplasia are H-Y negative. Hum Genet 57:15-22.

Buaas FW, Val P, Swain A. 2009. The transcription co-factor CITED2 functions during sex determination and early gonad development. Hum Mol Genet 18:2989-3001.

Calvari V, Bertini V, De Grandi A, Peverali G, Zuffardi O, Ferguson-Smith M, Knudtzon J, Camerino G, Borsani G, Guioli S. 2000. A new submicroscopic deletion that refines the $9 p$ region for sex reversal. Genomics 65:203-212.

Camerino G, Parma P, Radi O, Valentini S. 2006. Sex determination and sex reversal. Curr Opin Genet Dev 16:289-292.

Chen CP, Lin SP, Chen MR, Su JW, Chern SR, Chen YJ, Lee MS, Wang W. 2012. Phenotypic features of pure $9 p$ deletion in a male infant include cryptorchidism, congenital heart defects and postaxial polydactyly. Genet Couns 23:195-200.

Correa SM, Washburn LL, Kahlon RS, Musson MC, Bouma GJ, Eicher EM, Albrecht KH. 2012. Sex reversal in C57BL/6J XY mice caused by increased expression of ovarian genes and insufficient activation of the testis determining pathway. PLoS Genet 8:e100259.

Crocker M, Coghill SB, Cortinho R. 1988. An unbalanced autosomal translocation $(7 ; 9)$ associated with feminization. Clin Genet 34:70-73.

De Grouchy J, Turleau C. 1982. Monosomie 9p2. Atlas des maladies chromosomiques. Paris: Expansion Scientific Français. pp 162-167.

de Ravel TJ, Fryns JP, Van Driessche J, Vermeesch JR. 2004. Complex chromosome re-arrangement $45, \mathrm{X}, \mathrm{t}(\mathrm{Y} ; 9)$ in a girl with sex reversal and mental retardation. Am J Med Genet Part A 124A:259-262.

Edelmann L, Pandita RK, Morrow BE. 1999. Low-copy repeats mediate the common 3-Mb deletion in patients with velo-cardio-facial syndrome. Am J Hum Genet 64:1076-1086.

Eden MS, Thelin JW, Michalski K, Mitchell JA. 1985. Partial trisomy 6p and partial monosomy 9p from a de novo translocation 46,XY, -9, +DER(9)T (6:9)(p211:p24). Clin Genet 28:375-384.

Erickson RP, Skinner S, Jacquet H, Campion D, Buckley PG, Mantripragada KK, Dumanski JP. 2003. Does chromosome 22 have anything to do with sex determination: Further studies on a 46,XX,22q11.2 del male. Am J Med Genet Part A 123A:64-67.

Farrugia MK, Sebire NJ, Achermann JC, Eisawi A, Duffy PG, Mushtaq I. 2013. Clinical and gonadal features and early surgical management of 45 , $\mathrm{X} / 46, \mathrm{XY}$ and 45, X/47, XYY chromosomal mosaicism presenting with genital anomalies. J Pediatr Urol 9:139-144.

Flejter WL, Fergestad J, Gorski J, Varvill T, Chandrasekharappa S. 1998. A gene involved in XY sex reversal is located on chromosome 9, distal to marker D9S1779. Am J Hum Genet 63:794-802.

Freitas ÉL, Gribble SM, Simioni M, Vieira TP, Silva-Grecco RL, Balarin MA, Prigmore E, Krepischi-Santos AC, Rosenberg C, Szuhai K, van Haeringen A, Carter NP, Gil-da-Silva-Lopes VL. 2011. Maternally inherited partial monosomy $9 \mathrm{p}(\mathrm{pter} \rightarrow \mathrm{p} 24.1)$ and partial trisomy $20 \mathrm{p}$ 
(pter $\rightarrow$ p12.1) characterized by microarray comparative genomic hybridization. Am J Med Genet 155:2754-2761.

Fryns JP, Pedersen JC, Duyck H, Fabry G, Van den Berghe H. 1980. Deletion of the short arm of chromosome 9. A clinically recognisable entity. Eur J Pediatr 134:201-204.

Fryns JP, Kleczkowska A, Casaer P, van den Berghe H. 1986. Double autosomal chromosomal aberration ( $3 p$ trisomy/9p monosomy) and sex-reversal. Ann Génét 29:49-52.

Funderburk SJ, Sparkes RS, Klisak I. 1979. The 9p- syndrome. J Med Genet 16:75-79.

Garcia-Miñaur S, Fantes J, Murray RS, Porteous ME, Strain L, Burns JE, Stephen J, Warner JP. 2002. A novel atypical 22q11.2 distal deletion in father and son. J Med Genet 39:E62.

Girirajan S, Rosenfeld JA, Cooper GM, Antonacci F, Siswara P, Itsara A, Vives L, Walsh T, McCarthy SE, Baker C, Mefford HC, Kidd JM, Browning SR, Browning BL, Dickel DE, Levy DL, Ballif BC, Platky K, Farber DM, Gowans GC, Wetherbee JJ, Asamoah A, Weaver DD, Mark PR, Dickerson J, Garg BP, Ellingwood SA, Smith R, Banks VC, Smith W, McDonald MT, Hoo JJ, French BN, Hudson C, Johnson JP, Ozmore JR, Moeschler JB, Surti U, Escobar LF, El-Khechen D, Gorski JL, Kussmann J, Salbert B, Lacassie Y, Biser A, McDonald-McGinn DM, Zackai EH, Deardorff MA, Shaikh TH, Haan E, Friend KL, Fichera M, Romano C, Gécz J, DeLisi LE, Sebat J, King MC, Shaffer LG, Eichler EE. 2010. A recurrent 16p12.1 microdeletion supports a two-hit model for severe developmental delay. Nat Genet 42:203-209.

Guioli S, Schmitt K, Critcher R, Bouzyk M, Spurr NK, Ogata T, Hoo JJ, Pinsky L, Gimelli G, Pasztor L, Goodfellow PN. 1998. Molecular analysis of $9 p$ deletions associated with XY sex reversal: Refining the localization of a sex-determining gene to the tip of the chromosome. Am J Hum Genet 63:905-908.

Hauge X, Raca G, Cooper S, May K, Spiro R, Adam M, Martin CL. 2008. Detailed characterization of, and clinical correlations in, 10 patients with distal deletions of chromosome 9p. Genet Med 10:599-611.

Hawkins JR, Taylor A, Berta P, Levilliers J, Van der Auwera B, Goodfellow PN. 1992. Mutational analysis of SRY: Nonsense and missense mutations in XY sex reversal. Hum Genet 88:471-474.

Hayashi S, Kurosawa K, Imoto I, Mizutani S, Inazawa J. 2005. Detection of cryptic chromosome aberrations in a patient with a balanced $t(1 ; 9)$ (p34.2;p24) by array-based comparative genomic hybridization. Am J Med Genet Part A 139A:32-36.

Hernandez A, Rivera H, Jiménez-Sainz M, Fragoso R, Nazara Z, Cantú JM. 1979. Type and contretype signs in monosomy and trisomy 9p. On a case 46,XY, del (9)(pter yields p12:). Ann Génét 22:155-157.

Hoo JJ. 1986. Critical segment for 9p deletion syndrome. Clin Genet 29:541-542.

Hoo JJ, Salafsky IS, Lin CC. 1989. Possible localization of a recessive testis forming gene on 9p24. Am J Hum Genet (Suppl) 45:A78.

Hughes IA. 2008. Disorders of sex development: A new definition and classification. Best Pract Res Clin Endocrinol Metab 22:119-134.

Huret JL, Leonard C, Forestier B, Rethoré MO, Lejeune J. 1988. Eleven new cases of $\operatorname{del}(9 p)$ and features from 80 cases. J Med Genet 25:741-749.

Ioan D, Dumitriu L, Muşețeanu P, Bereliuc L, Belengeanu V, Maximilian C. 1985. Partial 9p monosomy-A case with hypothyroidism. Endocrinologie 23:279-281.

Jotterand M, Juillard E. 1976. A new case of trisomy for the distal part of 13q due to maternal translocation, $t(9 ; 13)(\mathrm{p} 21 ; \mathrm{q} 21)$. Hum Genet 33:213222.

Kadotani T, Watanabe Y, Kurose Y. 1984. A case of partial monosomy for the short arm of the chromosome No. 9. Proc Japan Acad 60:24-27.
Kanetsky PA, Mitra N, Vardhanabhuti S, Vaughn DJ, Li M, Ciosek SL, Letrero R, D'Andrea K, Vaddi M, Doody DR, Weaver J, Chen C, Starr JR, Håkonarson H, Rader DJ, Godwin AK, Reilly MP, Schwartz SM, Nathanson KL. 2011. A second independent locus within DMRT1 is associated with testicular germ cell tumor susceptibility. Hum Mol Genet 20:3109-3117.

Kozma C, Haddad BR, Meck JM. 2000. Trisomy 7p resulting from 7p15;9p24 translocation: Report of a new case and review of associated medical complications. Am J Med Genet 91:286-290.

Kratz CP, Han SS, Rosenberg PS, Berndt SI, Burdett L, Yeager M, Korde LA, Mai PL, Pfeiffer R, Greene MH. 2011. Variants in or near KITLG, BAK1, DMRT1, and TERT-CLPTM1L predispose to familial testicular germ cell tumour. J Med Genet 48:473-476.

Krentz AD, Murphy MW, Kim S, Cook MS, Capel B, Zhu R, Matin A, Sarver AL, Parker KL, Griswold MD, Looijenga LH, Bardwell VJ, Zarkower D. 2009. The DM domain protein DMRT1 is a dose-sensitive regulator of fetal germ cell proliferation and pluripotency. Proc Natl Acad Sci USA 106:22323-22328.

Lau YF. 1999. Gonadoblastoma, testicular and prostate cancers, and the TSPY gene. Am J Hum Genet 64:921-927.

Ledig S, Hiort O, Scherer G, Hoffmann M, Wolff G, Morlot S, Kuechler A, Wieacker P. 2010. Array-CGH analysis in patients with syndromic and non-syndromic XY gonadal dysgenesis: Evaluation of array CGH as diagnostic tool and search for new candidate loci. Hum Reprod 25:26372646.

Ledig S, Hiort O, Wünsch L, Wieacker P. 2012. Partial deletion of DMRT1 causes 46,XY ovotesticular disorder of sexual development. Eur J Endocrinol 167:119-124.

Lee IW, Chou YY, Hsu KF, Chou PY, Chen M, Kuo PL, Lin SJ. 2011. Complex chromosome rearrangement 46,XY, $\operatorname{der}(9) \mathrm{t}(\mathrm{Y} ; 9)(\mathrm{q} 12 ; \mathrm{p} 23)$ in a girl with sex reversal and mental retardation. Urology 77:12131216.

Leung AK, Rudd NL. 1988. A case of ring (9)/de(19p) mosaicism associated with gastroesophageal reflux. Am J Med Genet 29:43-48.

Livadas S, Mavrou A, Sofocleous C, van Vliet-Constantinidou C, Dracopoulou M, Dacou-Voutetakis C. 2003. Gonadoblastoma in a patient with $\operatorname{del}(9)(\mathrm{p} 22)$ and sex reversal: Report of a case and review of the literature. Cancer Genet Cytogenet 143:174-177.

Looijenga LH, Hersmus R, de Leeuw BH, Stoop H, Cools M, Oosterhuis JW, Drop SL, Wolffenbuttel KP. 2010. Gonadal tumours and DSD. Best Pract Res Clin Endocrinol Metab 24:291-310.

Lourenço D, Brauner R, Rybczynska M, Nihoul-Fékété C, McElreavey K, Bashamboo A. 2011. Loss-of-function mutation in GATA4 causes anomalies of human testicular development. Proc Natl Acad Sci USA 108:1597-1602.

Lupski JR. 2012. Digenic inheritance and Mendelian disease. Nat Genet 44:1291-1292.

Lytle C, Wade J, Farrier A, Flohrschutz F III, Hecht B, Allanson J. 1989. Duplication 6p and deletion 9p. J Med Genet 26:64-66.

Magenis RE, Allen LJ, Brown MG, Dougherty TM, Black M, HafitsBorchardt V, Toth-Fejel S, Lawce H, Smith L. 1990. 9p monosomy associated with XY gonadal dysgenesis: A contiguous gene syndrome? Am J Hum Genet (Suppl) 47:A33.

Matson CK, Murphy MW, Sarver AL, Griswold MD, Bardwell VJ, Zarkower D. 2011. DMRT1 prevents female reprogramming in the postnatal mammalian testis. Nature 476:101-104.

Matson CK, Zarkower D. 2012. Sex and the singular DM domain: Insights into sexual regulation, evolution and plasticity. Nat Rev Genet 13:163174. 
McDermid HE, Morrow BE. 2002. Genomic disorders on 22q11. Am J Hum Genet 70:1077-1088.

McDonald MT, Flejter W, Sheldon S, Putzi MJ, Gorski JL. 1997. XY sex reversal and gonadal dysgenesis due to 9p24 monosomy. Am J Med Genet $73: 321-326$

Monaghan HP, Howard NJ. 1981. Short stature and microgenitalia in the 9p-syndrome. Ir J Med Sci 150:382-384.

Muroya K, Okuyama T, Goishi K, Ogiso Y, Fukuda S, Kameyama J, Sato H, Suzuki Y, Terasaki H, Gomyo H, Wakui K, Fukushima Y, Ogata T. 2000. Sex-determining gene(s) on distal 9p: Clinical and molecular studies in six cases. J Clin Endocrinol Metab 85:3094-3100.

Neira VA, Córdova-Fletes C, Grondin Y, Ramirez-Velazco A, Figuera LE, Ortíz-López R, Barbaro M. 2012. Complex 9p rearrangement in an XY patient with ambiguous genitalia and features of both $9 \mathrm{p}$ duplication and deletion. Am J Med Genet Part A 158A:1498-1502.

Nielsen J, Homma A, Christiansen F, Rasmussen K, Saldaña-Garcia P. 1977. The deletion 9p syndrome. A 61-year-old man with deletion of short arm 9. Clin Genet 12:80-84.

Ogata T, Muroya K, Matsuo N, Hata J, Fukushima Y, Suzuki Y. 1997. Impaired male sex development in an infant with molecularly defined partial 9p monosomy: Implication for a testis forming gene(s) on 9p. J Med Genet 34:331-334.

Ogilvie CM, Ahn JW, Mann K, Roberts RG, Flinter F. 2009. A novel deletion in proximal $22 \mathrm{q}$ associated with cardiac septal defects and microcephaly: A case report. Mol Cytogenet 2:9.

Onesimo R, Orteschi D, Scalzone M, Rossodivita A, Nanni L, Zannoni GF Marrocco G, Battaglia D, Fundarò C, Neri G. 2012. Chromosome 9p deletion syndrome and sex reversal: Novel findings and redefinition of the critically deleted regions. Am J Med Genet Part A 158A:22662271.

Ostrer H. 2004. Alterations of sex differentiation in males: From candidate genes to diagnosis and treatments. Curr Pharm Des 10:501-511.

Ounap K, Uibo O, Zordania R, Kiho L, Ilus T, Oiglane-Shlik E, Bartsch O. 2004. Three patients with 9p deletions including DMRT1 and DMR T2: A girl with XY complement, bilateral ovotestes, and extreme growth retardation, and two XX females with normal pubertal development. Am J Med Genet Part A 130A:415-423.

Page DC. 1987. Hypothesis: A Y-chromosomal gene causes gonadoblastoma in dysgenetic gonads. Development 101Suppl:151-155.

Pavone L, Mollica F, Sorge G, Sciacca F, d'Agata A, Laurence KM. 1978. Partial monosomy 9. Ann Génét 21:186-188.

Phelan MC, Rogers RC, Crawford EC, Brown LG, Page DC. 2002. Velocardiofacial syndrome in an unexplained XX male. Am J Med Genet Part A 116A:77-79.

Philibert P, Leprieur E, Zenaty D, Thibaud E, Polak M, Frances AM, Lespinasse J, Raingeard I, Servant N, Audran F, Paris F, Sultan C. 2010. Steriodogenic factor-1 (SF-1) gene mutation as a frequent cause of primary amenorrhea in 46,XY female adolescents with low testosterone concentration. Reprod Biol Endocrinol 8:28-33.

Prieto F, Badia L, Asensi F, Roques V. 1980. Two reciprocal translocations t $(9 \mathrm{p}+; 13 \mathrm{q}-)$ and $\mathrm{t}(13 \mathrm{q}-; 21 \mathrm{q}+)$ : A study of the families. Hum Genet 54:7-11.

Rauch A, Zink S, Zweier C, Thiel CT, Koch A, Rauch R, Lascorz J, Hüffmeier U, Weyand M, Singer H, Hofbeck M. 2005. Systematic assessment of atypical deletions reveals genotype-phenotype correlation in $22 \mathrm{q} 11.2$. J Med Genet 42:871-876.

Raymond CS, Shamu CE, Shen MM, Seifert KJ, Hirsch B, Hodgkin J, Zarkower D. 1998. Evidence for evolutionary conservation of sex-determining genes. Nature 391:691-695.
Raymond CS, Parker ED, Kettlewell JR, Brown LG, Page DC, Kusz K, Jaruzelska J, Reinberg Y, Flejter WL, Bardwell VJ, Hirsch B, Zarkower D. 1999. A region of human chromosome 9p required for testis development contains two genes related to known sexual regulators. Hum Mol Genet 8:989-996.

Raymond CS, Murphy MW, O'Sullivan MG, Bardwell VJ, Zarkower D. 2000. Dmrt1, a gene related to worm and fly sexual regulators, is required for mammalian testis differentiation. Genes Dev 14:2587-2595.

Reamon-Buettner SM, Borlak J. 2005. GATA4 zinc finger mutations as a molecular rationale for septation defects of the human heart. J Med Genet 42:e32.

Recalcati MP, Bellini M, Norsa L, Ballarati L, Caselli R, Russo S, Larizza L, Giardino D. 2012. Complex rearrangement involving 9p deletion and duplication in a syndromic patient: Genotype/phenotype correlation and review of the literature. Gene 502:40-45.

Schimmenti LA, Higgins RR, Mendelsohn NJ, Casey TM, Steinberger J, Mammel MC, Wiesner GL. 1995. Monosomy 9p24->pter and trisomy $5 \mathrm{q} 31->$ qter: Case report and review of two cases. Am J Med Genet $57: 52-56$.

Schinzel A. 2001. 9p- syndrome. Catalogue of unbalanced chromosome aberrations in man. New York: De Gruyter. pp 399-400.

Sekido R, Lovell-Badge R. 2009. Sex determination and SRY: Down to a wink and a nudge? Trends Genet 25:19-29.

Senée V, Chelala C, Duchatelet S, Feng D, Blanc H, Cossec JC, Charon C, Nicolino M, Boileau P, Cavener DR, Bougnères P, Taha D, Julier C. 2006. Mutations in GLIS3 are responsible for a rare syndrome with neonatal diabetes mellitus and congenital hypothyroidism. Nat Genet 38:682-687.

Serville F, Allain D, Broustet A, Martin C, Gachet M, Babin JP, Cenraud J. 1976. Partial deletion of the short arm of the chromosome 9. Ann Génét 19:143.

Shan Z, Zabel B, Trautmann U, Hillig U, Ottolenghi C, Wan Y, Haaf T. 2000. FISH mapping of the sex-reversal region on human chromosome $9 p$ in two XY females and in primates. Eur J Hum Genet 8:167-173.

Shashi V, Berry D, Stamper TH, Pettenati M. 1998. A further case of choanal atresia in the deletion (9p) syndrome. Am J Med Genet 80:440.

Shimojima K, Yamamoto T. 2009. Investigation of the candidate region for trigonocephaly in a patient with monosomy $9 \mathrm{p}$ syndrome using arrayCGH. Am J Med Genet 149:1076-1080.

Sultana R, Myerson D, Disteche CM. 1995. In situ hybridization analysis of the Y chromosome in gonadoblastoma. Genes Chromosomes Cancer $13: 257-262$.

Swinkels ME, Simons A, Smeets DF, Vissers LE, Veltman JA, Pfundt R, de Vries BB, Faas BH, Schrander-Stumpel CT, McCann E, Sweeney E, May P, Draaisma JM, Knoers NV, van Kessel AG, van Ravenswaaij-Arts CM. 2008. Clinical and cytogenetic characterization of 13 Dutch patients with deletion 9p syndrome: Delineation of the critical region for a consensus phenotype. Am J Med Genet Part A 146A:1430-1438.

Szymańska J, Gutkowska A, Kubalska J, Krajewska-Walasek M, Wiśniewski L. 1984. 9p-syndrome: Two new observations. Klin Pädiatr 196:121.

Taylor LD, Krizman DB, Jankovic J, Hayani A, Steuber PC, Greenberg F, Fenwick RG, Caskey CT. 1991. 9p monosomy in a patient with Gilles de la Tourette's syndrome. Neurology 41:1513-1515.

Tosson H, Rose SR, Gartner LA. 2012. Description of children with 45,X/46, XY karyotype. Eur J Pediatr 171:521-529.

Turnbull C, Rapley EA, Seal S, Pernet D, Renwick A, Hughes D, Ricketts M, Linger R, Nsengimana J, Deloukas P, Huddart RA, Bishop DT, Easton DF, Stratton MR, Rahman N, UK Testicular Cancer Collaboration. 2010 Variants near DMRT1, TERT and ATF7IP are associated with testicular germ cell cancer Nat Genet 42:604-607. 
Uhlenhaut NH, Jakob S, Anlag K, Eisenberger T, Sekido R, Kress J, Treier AC, Klugmann C, Klasen C, Holter NI, Riethmacher D, Schütz G, Cooney AJ, Lovell-Badge R, Treier M. 2009. Somatic sex reprogramming of adult ovaries to testes by FOXL2 ablation. Cell 139:1130-1142.

Vásquez-Velásquez AI, Arnaud-López L, Figuera LE, Padilla-Gutiérrez JR, Rivas F, Rivera H. 2005. Ambiguous genitalia by 9p deletion inherent to a $\operatorname{dic}(\mathrm{Y} ; 9)(\mathrm{q} 12 ; \mathrm{p} 24)$. J Appl Genet 46:415-418.

Vásquez-Velásquez AI, García-Castillo HA, González-Mercado MG, Dávalos IP, Raca G, Xu X, Dwyer E, Rivera H. 2011. Duplication 5q and deletion $9 \mathrm{p}$ due to a $\mathrm{t}(5 ; 9)(\mathrm{q} 34 ; \mathrm{p} 23)$ in 2 cousins with features of Hunter-McAlpine syndrome and hypothyroidism. Cytogenet Genome Res 132:233-238.

Veitia R, Nunes M, Brauner R, Doco-Fenzy M, Joanny-Flinois O, Jaubert F, Lortat-Jacob S, Fellous M, McElreavey K. 1997. Deletions of distal 9p associated with $46, \mathrm{XY}$ male to female sex reversal: Definition of the breakpoints at 9p23.3-p24.1. Genomics 41:271-274.

Veitia RA, Nunes M, Quintana-Murci L, Rappaport R, Thibaud E, Jaubert F, Fellous M, McElreavey K, Gonçalves J, Silva M, Rodrigues JC, Caspurro M, Boieiro F, Marques R, Lavinha J. 1998. Swyer syndrome and 46,XY partial gonadal dysgenesis associated with $9 \mathrm{p}$ deletions in the absence of monosomy-9p syndrome. Am J Hum Genet 63:901-905.

Velagaleti GV, Hawkins JC, Panova NI, Lockhart LH. 2008. Partial trisomy and partial monosomy resulting from a reciprocal segregating in a large family. Indian J Pediatr 75:956-960.

Vialard F, Ottolenghi C, Gonzales M, Choiset A, Girard S, Siffroi JP, McElreavey K, Vibert-Guigue C, Sebaoun M, Joyé N, Portnoï MF, Jaubert
F, Fellous M. 2002. Deletion of 9p associated with gonadal dysfunction in 46,XY but not in 46,XX human fetuses. J Med Genet 39:514-518.

Vinci G, Chantot-Bastaraud S, El Houate B, Lortat-Jacob S, Brauner R, McElreavey K. 2007. Association of deletion 9p, 46, XY gonadal dysgenesis and autistic spectrum disorder. Mol Hum Reprod 13:685-689.

Wilhelm O, Osztovics M. 1982. 9p deletion syndrome. Acta Paediatr Acad Sci Hung 23:247-251.

Witters I, Vermeesch JR, Moerman PH, Fryns JP. 2004. Partial trisomy 3p/ monosomy 9p with sex reversal. Ultrasound Obstet Gynecol 23:418-419.

Wouters CH, van Bodegom TM, Moll HA, Govaerts LC. 1999. Partial trisomy $4 \mathrm{q}$ and monosomy $9 \mathrm{p}$ resulting from a familial translocation $\mathrm{t}$ $(4 ; 9)(\mathrm{q} 27 ; \mathrm{p} 24)$ in a child with choanal atresia. Ann Génét 42:160165 .

Young RS, Bader P, Palmer CG, Kaler SG, Hodes ME. 1983. Brief clinical report: Two children with de novo del(9p). Am J Med Genet 14:751757.

Yu S, Fiedler S, Stegner A, GrafWD. 2010. Genomic profile of copy number variants on the short arm of human chromosome 8. Eur J Hum Genet 18:1114-1120.

Yu S, Zhou XG, Fiedler SD, Brawner SJ, Joyce JM, Liu HY. 2011. Cardiac defects are infrequent findings in individuals with 8p23.1 genomic duplications containing GATA4. Circ Cardiovasc Genet 4:620-625.

Zhu L, Wilken J, Phillips NB, Narendra U, Chan G, Stratton SM, Kent SB, Weiss MA. 2000. Sexual dimorphism in diverse metazoans is regulated by a novel class of intertwined zinc fingers. Genes Dev 14:1750-1764. 